\title{
THE EFFECTS OF THE CULTURAL AND CREATIVE SECTOR ON EMPLOYMENT AND WAGES: THE CASE OF RIO GRANDE DO SUL, BRAZIL, FROM 2000 TO 2010
}

Judite Sanson De BEM*, Nelci Maria Richter GIACOMINI, University Center La Salle (UNILASALLE), Rio Grande do Sul, Brazil.

\begin{abstract}
Culture was not always considered a relevant area of study for economics. It started being important in the 1960s when resources became scarce and the choices of what to finance started to be questioned. From the viewpoint of economy, in some regions, the cultural sector exhibits impacts at a higher rate than the rest of the economy. One of the impacts is the performance of the variable "employment" and its multiplier effects. In fact, the different segments that constitute the sector of creative economy offer several different possibilities to develop highly skilled activities. By using primary data from the Ministry of Labor and Employment (MTE)/ Annual Social Information Report (RAIS)/ General Registry of Employed and Unemployed Individuals (CAGED), the aim of this paper is to discuss the importance of the activities that comprise the creative industries, with a specific focus on the State of Rio Grande do Sul regarding job generation and wages between 2000 and 2010. During the period studied, it was observed that both employment as well as wages decreased in the creative sector, a consequence of the crisis at the end of the 2000s, as well as of the growth of other segments that was more intense than those related to creativity. It is notew orthy that there is room for different creative segments to increase in participation in the productive structure of the State.

Keywords: creative industry, employment, wages, Rio Grande do Sul
\end{abstract}

\section{Introduction}

Culture, or the activities related to it, has been recently studied by Economics, because in Economics there is no clear definition for it (see Quote 1 in the Appendix). According to Throsby (2001), culture could be defined in two different ways (see Quote 2 in the Appendix).

Theorizing about the economic importance of culture is something recent. It started, especially in the 1960s with a study by William Bowen and William Baumol. However, it was in the 1990s that publications started to show a greater formalization among economy, culture, production and consumption of cultural goods and other definitions.

But, what kinds of relationships can be developed involving culture? Based on Throsby's concept (2001) explained above, "[...]denoting certain activities that are undertaken by people, and the products of those activities, which have to do with the intellectual, moral and artistic aspects of human life [...]", aspects such as job generation, income, public and private spending, public policies, revenues and spending on cultural

\footnotetext{
* Prof. Dr. Judite Sanson de Bem*, Economist, Professor of the Graduate Program in Social Memory and Cultural Heritage of La Salle University Center (UNILASALLE), Rio Grande do Sul; Brazil.. E-mail: jsanson@terra.com.br; Address: 231, Giordano Bruno Street, ap. 21- Rio Branco District, Porto Alegre, Rio Grande do Sul, Brazil. Zip Code: 90420-150

Prof. Ms. Nelci Maria Richter Giacomini, Professor of the Undergraduate Course in Economics and researcher at the University Center La Salle (UNILASALLE), Rio Grande do Sul, Brazil.

E-mail: nelcig@uol.com.br; Address: 144, Icaraí Av., Cristal District, Porto Alegre, Rio Grande do Sul, Brazil. .Zip Code: 90810-000

Acknowledgement: We would like to thank Prof.Dr. Lucas Graegg for his comments and suggestions for this article.
} 
goods, investments, profits, etc. Therefore, economics and culture are complementary fields of study.

In Brazil, culture and its economic relations were initially established by projects such as Diagnosis of Investments in Culture in Brazil - Mnc/João Pinheiro Foundation (FJP) Minas Gerais (1997) or System of Cultural Information and Indicators (IBGE/ MnC-2006), or Cultural Indicators: Possibilities and Limits - IBGE bases (Mnc , 2006). In addition to these research centers and authors, the Federal University of Bahia, the Federation of Industries of Rio de Janeiro, the Federal University of Rio Grande do Sul and other institutions gradually started to focus on this issue.

But, the road to recognition of culture as relevant to the Brazilian economy was complemented in 2012, with the establishment of the Creative Economy Secretariat (SEC) linked to the Ministry of Culture.

Only in the second decade of 2000, the State of Rio Grande do Sul assumed that the cultural and creative sector has a key role in development of the state, because of the benefits resulting from the Gross Domestic Product (GDP) growth rate, taxation, competitiveness, in the external sector, in employment and in the generation of technological innovations, among others. An example were the 2003 FAPERGS and $\mathrm{CNPq} / \mathrm{Minc}$ public notices. There is a growing interest in making segments of the cultural industry more dynamic, especially those related to information technology, design, architecture, fashion, etc., since their multiplier effects on employment and income are relevant.

To develop this study, we cannot understand as synonymous the activities of cultural production, cultural industry and creative industry. The concern of the Federal Government and the State Government of RS has been the latter, since it refers to a set of activities with a greater range of segments than the first.

\subsection{Main objective}

By understanding the conceptual difference among culture, creative industry and cultural industry, the main objective of this article is to interpret the importance of the first in relation to the development of a region. It also aims to verify the behavior of employment and wages data in the creative sector in the state of Rio Grande do Sul, between 2000 and 2010.

1.2 Methodology and data collection

This is a descriptive study. As a data source, we used the General Registry of Employed and Unemployed Individuals (CAGED) database/Ministry of Labor and Employment (MTE) for the period of 2000 to 2010. Among the variables available in this database, we selected the number of employment relationships, hereinafter called employment, and the average monthly wage earned in the creative sector. The conceptual division for the different segments of the creative industry was taken from the study by FIRJAN (2011) and United Nations Conference on Trade and Development (UNCTAD, 2011). The study developed by UNCTAD is an international reference concerning the definition and division of the different links in the creative industry chain. References from UNESCO and the European Union were also used.

We opted for the study of creative industry, rather than the cultural industry, as the first covers the second and adds some segments, such as design, architecture and advertising. This paper consists of two parts, besides the introduction and conclusion: first, we present a literature review on what is meant by creative activities and their economic divisions. We will also present some effects of these activities on economic development. Subsequently, a second part presents data on employment and wages in the state of Rio Grande do Sul and their behavior between 2000 and 2010. 


\section{Culture, Economy and Creative Activities: Brief Considerations on the Economic and Social Effects}

As suggested by David Throsby (2001), the word "culture" is used in different ways in everyday life, but it does not have a sufficiently tangible or generally accepted definition. Also, according to the author, the term gradually changed from a sense of growing crops to the overall development of a society or nation. In the latter sense, culture and its activities can be considered an integrating part of contemporary societies.

From an analytical point of view, it is possible to understand culture from different viewpoints. In social sciences, it is a vast field that ranges from the practices of small human groups immersed in their networks of meaning (GEERTZ, 2008), to Bourdieu's concepts of capital and cultural reproduction (BOURDIEU, 2007), until the idea of culture "as a self-consciousness of modern society" (BAUMAN, 2012, p. 8).

In the particular case of economy, there is a consensus that culture was not always something of interest, as there was not a clear understanding of its effects on different indicators such as employment, income, taxes, among others. The study of the influence of the production of cultural goods and services in the development of territories became known in the 1960s, with the pioneering study by Baumol, W. and E. G. Bowen (1966), Performing Arts - The Economic Dilemma: Common to Theater, Opera, Music, and Dance, Cambridge, MT Press.

In the 1980s and 1990s, there was a growing interest in a new economic view on development; so, that it began to focus more on people (human capital) and less on goods and culture started to have an important role in this new approach and process. From this point of view, culture is also considered an investment in social capital, as an intermediate or final consumer of goods with strong spillover effects (REBELO, CORREIA, CRISTÓVÃO, 2011). Under this perspective, education is the basic assumption of the development and of the individual, who, when studying, would be "enhancing" himself similarly to capital appreciation. In this equation, capital and employment are equipped as if they were both equally mere "factors of production" (similar to neoclassical economic theories), and, as a result, investments in education and culture would be also determined by the criteria of capitalist investment, as they become key economic factors for development.

Regarding the interest of international organizations such as the United Nations, UNESCO, the European Union, the World Bank and the International Monetary Fund, the cultural sector, through culture industry and creative industry, starts to play a key role, through positive impulses on employment, innovations, exports and other spillovers. According to the Organization for Economic Co-operation and Development (OECD, 2011), culture can influence regional economic development (see Quote 3 in the Appendix).

In the 1990s, two independent processes emerged, giving rise to what is described, on the one side, as' economization' of culture, and, on the other side, "culturalization' of economy. Thus, cultural activities began to stand out increasingly for its dual nature, being economic and cultural at the same time. The importance of culture and its different segments of productive activities as society boosters started to be definitively justified. (EU, 2011). In another quotation (see Quote 4 in the Appendix) they say culture is ideally placed at the boundary between economy and the political domain.

Despite the recognition of the importance of the cultural sector for the "knowledge economy" and for the economic and social development of the different regions, the issue is still neglected by major currents of thought, according to the document "The Economy of Culture in Europe" (US, 2011). Among the different benefits of culture to society, Table provides a summary. 
Table 1 - Benefits of Culture to Society

\begin{tabular}{|c|c|}
\hline $\begin{array}{l}\text { Access to culture }= \\
\text { Access the culture as } \\
\text { democratic empowerment }\end{array}$ & $\begin{array}{l}\text { It is of primary importance the idea that cultural development is one of the } \\
\text { conditions that enables an effective practice of democracy" } 2 \text {. According to Jean } \\
\text { Rigaud, the first and most important objective of any cultural policy is to } \\
\text { ensure that every single person gets the opportunity to shape their "citizen' } \\
\text { awareness", by ensuring a concrete equal access to culture. In the sector of the } \\
\text { performing arts, Baumol and Bowen }{ }^{3} \text { have shown that the low productivity } \\
\text { gains in artistic production , associated with the inevitable rise in artists' } \\
\text { salaries, result in the inevitable rise in costs and ticket prices (the so-called } \\
\text { "cost disease"). Thus, in order to ensure the existence of performing arts, } \\
\text { mainly because they contribute to the "enlightenment" of citizens, they must } \\
\text { be supported with sponsorships or with public support. In other sectors, } \\
\text { which are not marked by such productivity gap, public intervention may be } \\
\text { necessary to ensure a variety of offerings. Indeed, one of the characteristics of } \\
\text { cultural products is the high level of uncertainty inherent to them. Hence, } \\
\text { there is a tendency to produce products whose success is almost guaranteed in } \\
\text { detriment of a variety of offerings of products whose sale may raise doubts. }\end{array}$ \\
\hline $\begin{array}{l}\text { Access to } \\
\text { culture as } \\
\text { education }\end{array}$ & $\begin{array}{l}\text { Culture has a complex educational value. The point is not only to make people } \\
\text { understand "high culture", but to have access and to participate in culture } \\
\text { because it acts as a mind-opener. The diversity of cultures acts as an incentive } \\
\text { to learn other realities and perspectives and to encourage tolerance. In } \\
\text { addition, education in arts provides skills that are "transferable" to other } \\
\text { sectors such as being open, being able to listen to the others, having a team } \\
\text { spirit and a spirit of cooperation, concentration, imagination, etc. }\end{array}$ \\
\hline $\begin{array}{l}\text { A strong cultural sector as a a } \\
\text { flag-bearer for national and } \\
\text { supra-national values }\end{array}$ & $\begin{array}{l}\text { Culture acts like a cultural ambassador. It is a way of promoting values such as } \\
\text { tolerance, freedom of speech, democracy and peace. From an interactive } \\
\text { perspective, culture is a precious tool in supporting an inter-cultural dialogue } \\
\text { within different regions, as well as between a given country and the rest of the } \\
\text { world. }\end{array}$ \\
\hline $\begin{array}{l}\text { Participation in and access to } \\
\text { a diverse cultural sector, } \\
\text { reinforces identity/ building } \\
\text { and of a sense of "belonging" }\end{array}$ & $\begin{array}{l}\text { Culture helps promote identity building at local and national levels. In } \\
\text { this case, identity building does not refer to the values promoted towards the } \\
\text { others, but to a sense of belonging fostered among individuals, in relation to } \\
\text { their surroundings, their nation, or of supra-national reference. }\end{array}$ \\
\hline $\begin{array}{l}\text { Participation and access for } \\
\text { all as a means of } \\
\text { social cohesion }\end{array}$ & $\begin{array}{l}\text { Culture also helps to integrate the different segments of the population by } \\
\text { supporting a diversity of languages and local communities. It has a role to play } \\
\text { in reinforcing social cohesion and inclusion. }\end{array}$ \\
\hline $\begin{array}{l}\text { Generation of } \\
\text { positive } \\
\text { externalities }= \\
\text { a legitimized } \\
\text { way of public intervention }\end{array}$ & $\begin{array}{l}\text { Culture generates "positive externalities" when the consumption of cultural } \\
\text { goods benefits the entire community. This is the case when the cultural } \\
\text { activity generates social and economic benefits in the immediate surroundings } \\
\text { (for example, the construction of the Guggenheim Bilbao museum has resulted } \\
\text { in positive externalities for the hotel and restoration sector, transport, cultural } \\
\text { associations in the area, other museums already established in Bilbao which } \\
\text { were refurnished, and it recorded an increased number of visitors, etc.) or } \\
\text { when the "image" and identity of a city are reinforced. }\end{array}$ \\
\hline $\begin{array}{l}\text { Expectation of high rates of } \\
\text { return on the investments = } \\
\text { public intervention } \\
\text { legitimized on the basis of } \\
\text { the expectation of economic } \\
\text { progress. }\end{array}$ & $\begin{array}{l}\text { In other parts of the cultural sector, some activities show fairly good } \\
\text { "productivity rates". In other words, culture has become a factor of economic } \\
\text { progress, in line with labor, capital and technological factors. } \\
\text { In this context, public support to culture (like public support to education) is } \\
\text { justified as a way to participate in improving economic growth. Thus, it is seen } \\
\text { as a strategic investment expected to entail high returns. }\end{array}$ \\
\hline
\end{tabular}

Source: Adapted from the European Commission Culture, 2006, p. 122-123. Notes: 2 Pour une refondation de la politique culturelle, Rapport au Ministre de la Culture, par Jacques Rigaud, président de la Commission d'étude de la politique culturelle de l'Etat, La Documentation Française, Paris 1996. 3 Baumol and Bowen carried out a seminal work in the sixties in relation to the situation of performing arts in New York. They demonstrated the "productivity lag" that marks the sector of performing arts to further justify the need for public intervention. 
The economic analysis of culture in terms of products and services has opened room for international discussions about what is meant by a cultural industry and all its different segments of interpretations and derivations. The European Union has set the following concepts (US, 2011a, p. 1):

\section{- Cultural Sector}

a) non-industrial sectors that produce not reproducible goods and services in order to be consumed openly (concerts, art exhibitions, performance). They can be subdivided into the visual arts fields (painting, crafts, sculpture, photography), performing arts or live presentations (opera, orchestra, theater, dance, circus, and heritage including museums, heritage and archaeological sites, libraries and records);

b) industrial sectors, in the sense that they produce finished cultural goods for mass reproduction and dissemination and exports. Here, there would be "cultural industries" of production of films and videos, video games, cinema, music, publishing books and other printed materials.

\section{- Creative Sector}

In the creative sector, culture becomes a creative and innovative input used in the production of intermediate consumer goods (not finished), including activities such as design (fashion, interior and product), architecture and advertising.

For the evaluation of the economic and social impacts of culture, particularly the industrial sectors, direct and indirect quantifiable effects can be considered both in product and in employment and other economic variables such as taxes, subsidies, investments, purchases, among others. Moreover, culture and innovation also affect the attraction of creative talent and the promotion of tourism. These direct and indirect effects (spillover effects) were described in Table 1.

UNESCO, in turn, provides two other definitions, a result of developments in the discussions in the area and of the evolution of the dynamics of world trade and information technology (See Quote 6 in the Appendix).

Important systematic efforts on cultural and creative sectors in Brazil were also carried out. A pioneer work was developed by the Federation of Industries of Rio de Janeiro (FIRJAN) . Figure 1 (See Quote 7 in the Appendix) shows the different links of the creative industry chain. That division was used in this article because it sets up a wide range of sectors and sub sectors besides being pioneering in national studies on the subject. This study was based on studies carried out by UNCTAD, the UN agency for trade and development.

Thus, while the term cultural industry was born in the Frankfurt School, led by Theodor Adorno and Max Horkheimer, " [...] defined as a set of economic activities that join the functions of design, creation and production of culture with more industrial functions of manufacturing and marketing of cultural products on a large scale [...]" (UNCTAD, 2011), it is clear that

"[...] the term "creative industries", which has been developed since then, has expanded the scope of cultural industries beyond the arts, establishing a change in approach to potential business activities, which, until recently, were considered pure or predominantly in non-economic terms."

Thus, the creative sector is broader than the cultural sector. With the development of technologies, some segments were included in the study because, for its production, it is necessary to adopt creativity, for instance fashion, architecture and information technology.

As the object of this study, the second part of this paper presents the case study of the State of Rio Grande do Sul (RS) and the increasing participation of the creative segment in the formulation of its productive activities. 


\section{The Creative Sector in the State of Rio Grande do Sul: the development of employment and wages between 2000 and 2010.}

As previously developed, culture and the creative sector create externalities reflecting in different areas of economy and of the society of a region. In accordance with this, they can be found in different regions. If we assume that one of the externalities is to generate jobs and income, this article will use the case of Rio Grande do Sul (RS), Brazil as an empirical part.

In 2010, the state of RS had a total population of 10,693,929 inhabitants, in an area of 281,748.50 square kilometers, a per capita GDP (2010) of R \$20,810 (estimation). In its social constitution, there is a strong presence of Italians, Germans and Portuguese people. Although there was immigration, mainly in the nineteenth century, its influence is seen until the twenty-first century, as the different economic activities of the regions reflect this settlement.

Some differences can be found in the economic and cultural activities: while the German regions, are mainly associated with shoe production and machinery, the Italian regions are linked to the production of beverages, furniture, clothing and metal-mechanic. The festivals are also relevant: the Italian regions celebrate the famous Grape Festival, the harvest festivals and, colonial festivals and the German regions celebrate the Oktoberfest, the festivals of the coffeecakes, etc.

To evaluate the importance of creative activities of RS we used the classification developed according to UNCTAD (2011) and FIRJAN (2012), shown in Figure 1 (above):

- Creative industry Nucleus - it is an adaptation of the 13 segments of the British study, referenced by UNCTAD document. The definition of the creative industry nucleus used in this study includes the segments of Cultural Expressions, Performing Arts, Visual Arts, Music, Film \& Video, TV \& Radio, Publishing Market, Software \& Computer Science, Architecture, Design, Fashion and Advertising. Thus, the nucleus consists essentially of services, whose main part of the production process is the creative activity;

- the related areas involve the segments of direct provision of goods and services to the nucleus and, in large part, consist of by industries and service companies that supply materials and basic elements to operate the nucleus;

- The last link of the chain Support Activities consists of a third group of more indirect activities: goods and services provision.

One example of the importance of employment in these industries is book production. The book's author will obtain all inputs to make his work feasible. In this respect, the preparation of the first draft (organization of the book) is considered the nucleus; the manufacturing of the printing presses, paper, ink, among others belong to the related industry. The marketing of the book is part of the support activity. Thus, we understand the economic and social importance of the creative industry. In addition to being understood as a set of links, therefore, a chain, the creative activity same can either be or be concentrated in a specific region, which refers to a Local Production System or LPS.

In the analyzed period from 2000 to 2010 , employment in the creative industry increased $11.33 \%$, while employment in all sectors/ activities of the state's economy has varied positively about $48.07 \%$, that is, variation or the positive effects were not as intense in the State (Figure 2). Another important finding is the inexpressive participation of the nucleus industries in the State.

The definition of nucleus of creative industry adopted in this study includes the segments of Cultural Expressions, Performing Arts, Visual Arts, Music, Film \& Video, TV \& 
Radio, Publishing Market, Software \& Computer Science, Architecture, Design, Fashion and Advertising. It is clear that the nucleus consists mainly of services, which have the creative activity as the main part of the production process. (FIRJAN, 2012, p. 13)

In 2010, for example, the last available year of the series at the time of the study corresponded to only $16.75 \%$ of the creative industry employment rate and the supporting activities corresponded to $25.18 \%$. In addition to the little participation of the nucleus activities, they decreased their participation in the period while in the support activities there was the reverse movement.

Among others, in RS, there was a positive progress of the employment rate in the creative industry by the year 2004 and a slowdown since then. It started to evolve at the end of the decade, despite the crisis of the years 2007, 2008 and 2009. This crisis, at the end of the first decade of the 2000, shook the world, especially the developed countries in Europe and North America. Rio Grande do Sul is one of the four major producers and exporters in Brazil; so, this crisis directly affected its economy, once its exports were destined to those countries in crisis.

In percentage terms, in the early 2000s, the RS creative industry accounted for $27.19 \%$ of the total employment in the State, while in 2010 the percentage had dropped to $20.45 \%$. These data show that different segments of "creativity" were little explored in the State, because there was a prevalence of sectors connected to agriculture and livestock (the state was even called "the Brazilian Barn"), metallurgy, mechanics, chemistry, beverages, among others.

\section{Figure 2 - Employment in the Creative Industry in RS - 2000-2010}

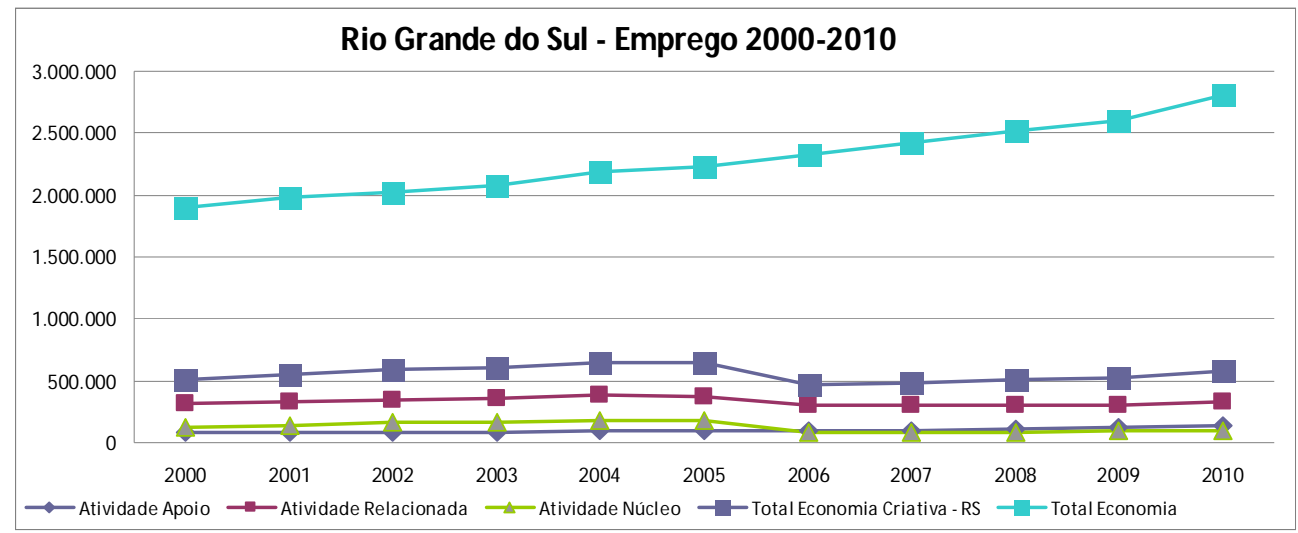

Source: MTE, 2011

Among the largest employers in the creative industry are the leather footwear manufacturing (located in Vale do Rio dos Sinos Region); Manufacturing of furniture, mainly wooden furniture (Mountains Region); Clothing and accessories retail (all laborintensive activities).

As for income (defined as wages), during the period considered, the following distribution (Figure 3) was observed among groups:

Except for the support activities, which had an increase of $16.61 \%$ in income, all the other activities decreased, with emphasis on nucleus activities $(-47.53 \%)$. It appears that this behavior (wages) of the entire state's economy also decreased (by $0.77 \%$ ) in this period, and it was not higher because the state of RS is strongly dependent on agribusiness and its ex-ant and ex-post links. 
Figure 3. Rio Grande do Sul, earned income from 2000 to 2010 - Creative Industry

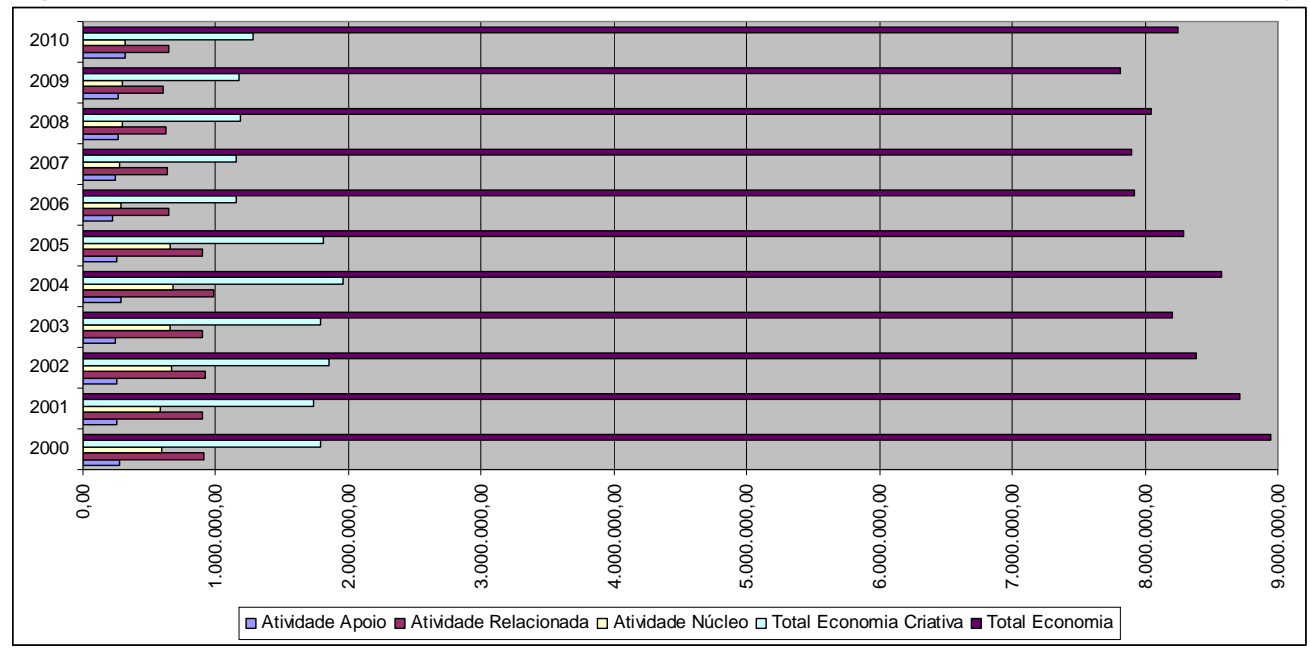

\section{Source: MTE 2011}

The average monthly wage per person working in the creative industry of the RS in 2000 was 3.47 minimum wages. In 2010, this amount decreased to 2.24 minimum wages per month.

Although the number of job vacancies has grown, the average wage has decreased, which means that the hires performed occurred with lower salaries. In the total of the economy, these values are higher than the creative industry, but they also showed a decreasing trend: in 2000, the average salary of economy was 4.72 minimum wages, while in 2010 this figure changed to 2.94 minimum wages. In terms of real purchasing power, using the index General Price Index-Internal Availability (IGP-DI), there was a decrease of $8.29 \%$ of the average salaries, compared to the years 2000 and 2010.

An important issue, which was not included in this article, is that some creative activities are carried out for a defined period, season, or there is in these segments a large proportion of youths and informal people, which partly explains the reduction in the average wages.

The creative activities with the highest average wages are tanning and other leather preparations; manufacturing of leather footwear; computer equipment manufacturing; manufacturing of furniture (mainly furniture made of wood); clothing and accessories retail; footwear and travel items retail; engineering services.

\section{CONCLUSION}

In an increasingly globalized world, the cultural production sector has gradually generated jobs and wealth. Thus, its development becomes indispensable for the competitiveness, employment and social cohesion of the regions. Culture, in a creative and innovative way, should be explored and promoted, because it is the basis for social and technological innovation and it boosts growth.

Cultural industries and the creative sector provided a significant contribution to employment and income in the economy of the state of RS. In 2010, more than 575,000 people worked in the cultural sector in RS, which is about $20.45 \%$ of the total employed population. 
These industries and the creativity they generate are an essential asset for the economy of the regions they are part of: both in terms of employment and wages and in terms of tax and export generation. Their importance goes beyond the two variables focused in this article. Their competitiveness generates positive externalities. An example is the provision of services such as engineering, design, information technology, among others, in an increasingly interdependent world. In terms of design, the State is an important footwear center and the main exporting companies are responsible for many sectors in these activities. Currently, there are 19 technological incubators in the State, including RAIAR (PUCRS), UNITEC (UNISINOS), ITEF (FEEVALE), CEI (UFRGS), among others. They are responsible for generating software and other products. However, some segments that belong to the creative industry had serious problems of employment and income, such as the footwear and furniture sectors.

Nevertheless, some concerns can be shown: why there has been a decline in employment in these occupations in RS and why does not the core sector have an important role yet? We believe that it is because the State has always been on the margins of the rest of the country in relation to the art market, dedicating to activities related to agribusiness and the metal-mechanic industry. However, this needs further explanation.

Thus, to those interested in the state of RS, we recommend the following:

- promoting creativity through young adult and adult education, inviting the cultural sector to participate in a concrete way and with instruments in the learning process through life;

- that the government creates more effective instruments to foster culture and art;

- including ways to boost cultural activities in formal and informal instruction to create a love for culture in people;

- promoting capacity development in the cultural sector, providing support to train management skills, entrepreneurship, knowledge of the market dimension in RS or of the commercial and cultural activities in the State;

- developing funding sources, including sponsorships, and a better access to them;

- developing creative partnerships between the cultural sector and other complementary sectors such as IT, research, tourism, sports, etc in order to strengthen social and economic impact of investments in culture and creativity, particularly the promotion, growth and employment;

- finally, developing, the power and attractiveness of the regions and towns (festivals, etc.) through culture.

\section{REFERENCES}

BAUMAN, Zigmunt. Ensaios sobre o conceito de cultura. Rio de Janeiro: Jorge Zahar Editor, 2012.

BOURDIEU, Pierre. A Distinção. São Paulo: EdUSP, 2007.

COMISSÃO DAS COMUNIDADES EUROPEIAS. Comunicação sobre uma agenda européia para a cultura num mundo globalizado. Bruxelas, SEC(2007) 570, Comissão das Comunidades Européias. Disponível em: < http:// eurlex.europa.eu/ LexUriServ/ LexUriServ.do?uri=COM:2007:0242:FIN:PT:PDF>. Acesso em: fev 2012.

CRISTÓVÃO, Artur (Coordenação), J. REBELO, A. Baptista, L. CORREIA, A. P. Rodrigues (2007), Uma rede para o futuro? Estudo de avaliação da COMUM - Rede Cultural, Vila Real, Universidade de Trás-os-Montes e Alto Douro, DESG/ CETRAD. 
EUROPE UNION - EU. The Economy of Culture in Europe. European Comission. Study prepared for the European Commission (Directorate-General for Education and Culture). KEA: 2006. Disponível em: http:/ / ec.europa.eu/ culture/ library/ studies/ culturaleconomy_en.pdf . Acesso em: dez. 2011.

EUROPEAN UNION - EU. The Economy of Culture in Europe- Executive Summary: European Comission, Disponível em: <http:/ / ec.europa.eu/ culture/ pdf/ doc895_en.pdf>. Acesso em: dez.2011a.

FEDERAÇÃO DAS INDÚSTRIAS ESTADO DO RIO DE JANEIRO - FIRJAN. A cadeia da indústria criativa no Brasil. Rio de Janeiro: FIRJAN. Estudos para o Desenvolvimento do Rio de Janeiro, no2 maio. 2008. Disponível em:

http:/ / www .firjan.org.br/ main.jsp?lumItemId=2C908CE9215B0DC40121737B1C8107C1 \&lumPageId=2C908CE9215B0DC40121793770A2082A. Acesso em: jan. 2012.

GEERTZ, Clifford . The Interpretation of Cultures. Rio de Janeiro : Guanabara Koogan , 2008.

GINSBURGH, Victor A.; THROSBY, David. Handbook of the Economics of Art and Culture. North-Holland: Elsevier, 2006.

OECD. Culture and Local Development. Paris: OECD Publishing. Disponível em: <http:/ / www.oecd.org/ document/ 50/ 0,2340,en_2649_34417_34918578_1_1_1_1,00.htm l>. Acesso em: dez. 2011.

REBELO, João; CORREIA, Leonilda; CRISTÓVÃO, Arthur. Redes culturais e desenvolvimento local: a experiência da COMUM. Disponível em: <http:/ / www.apdr.pt/ siteRPER/ numeros/ RPER15/ 15.2.pdf>. Acesso em: dez. 2011. THROSBY, David. The Production and Consumption of the Arts: A View of Cultural Economics. In Journal of Economic Literature, Vol. 32, nํㅜ 1, pp. 1-29. 1994.

THROSBY, David. Culture, Economics and Sustainability. In Journal of Cultural Economics, no 19, pp. 199-205. 1995.

THROSBY, David. Economics and Culture. Cambridge: Cambridge University Press , 2001 Disponível em: http:/ / assets.cambridge.org/ 052158/406X/ sample/ 052158406XWS.pdf. Acesso em: fev. 2014.

THROSBY, David. Cultural Capital. In Journal of Cultural Economics, no 23, pp. 3-12. 1999.

UNESCO. Understanding Creative Industries. Cultural Statistics for Public-policy Making. Disponível em: http:// portal.unesco.org/pv obj cache/ pv obj id 7D7822788289E0813D7CE385533915 A9E27A0100/ filename/cultural stat_EN.pdf. Acessado em: jan. 2013.

UNCTAD. Creative Economy. Report 2008. Geneva; New York: UNCTAD; UNDP, 2008, p. 9-16. <http:// www.unctad.org/ Templates/ WebFlyer.asp?intItemID=5109\&lang=1>. Acessado em: 10.out.2011. 
APPENDIX

\section{Quote 1, Thosby (2011)}

The original connotation of the word 'culture', of course, referred to the tillage of the soil. In the sixteenth century, this literal meaning became transposed to the cultivation of the mind and the intellect. Such figurative usage is still in active service today: we refer to someone well versed in the arts and letters as a 'cultured' or 'cultivated' person, and the noun 'culture' is often used without qualification to denote what, under a more restrictive definition, would be referred to as the products and practices of the 'high' arts. But, since the early nineteenth century the term 'culture' has been used in a broader sense to describe the intellectual and spiritual development of civilization as a whole. In turn, this usage became focused onto these same characteristics when evidenced in particular societies, such as nation states. In due course, this humanistic interpretation of culture was supplanted by a more all-encompassing concept whereby culture was seen to embrace not just intellectual endeavor, but the entire way of life of a people or society. (THROSBY, 2001)

\section{Quote(2), Thosby(2011)}

The first sense in which we shall use the word 'culture' is in a broadly anthropological or sociological framework to describe a set of attitudes, beliefs, mores, customs, values and practices, which are common to or shared by any group. The group may be defined in terms of politics, geography, religion, ethnicity or some other characteristic [...] The characteristics which define the group may be substantiated in the form of signs, symbols, texts, language, artifacts, oral and written tradition and by other means. This interpretation of culture will be especially useful for present purposes in examining the role of cultural factors in economic performance and the relationship between culture and economic development. The second definition of 'culture' has a more functional orientation, denoting certain activities that are undertaken by people, and the products of those activities, which have to do with the intellectual, moral and artistic aspects of human life. 'Culture' in this sense relates to activities drawing upon the enlightenment and education of the mind rather than the acquisition of purely technical or vocational skills. In such usage, the word is more likely to occur as an adjective than as a noun, as in 'cultural goods', 'cultural institutions', 'cultural industries' or the 'cultural sector of the economy'. To give this second definition more precision, let us propose that the connotation contained in this usage of the word 'culture' can be deemed to derive from certain more or less objectively definable characteristics of the activities concerned. Three such characteristics are suggested. They are: that the activities concerned involve some form of creativity in their production; that they are concerned with the generation and communication of symbolic meaning, and that their output embodies, at least potentially, some form of intellectual property. (THROSBY, 2001)

\section{Quote 3, OECD}


Culture is part of the local development. As well as at a national level, culture is also related to the generation of jobs, exports and revenues at a local level. Whether in the cities, metropolitan areas or regions, culture has become an essential component of quality of life, a source of tourism revenue and "a lever of creativity" of new goods and services. The contribution of culture to employment can range from 3 to $7 \%$ or more. Thus, it is no surprise that cultural tourism, stimulating districts and cultural neighborhoods, is high on local governments' agendas.

\section{Quote 4, European Union}

Culture is ideally placed at the boundary between economy and political domain. Compared to other sectors of economy, culture has an additional dimension - not only does it create wealth but it also contributes to social inclusion, better education, selfconfidence and the pride to belong to a historic community. Culture is, also, a powerful tool to communicate values and promote the objectives of public interest that are broader than the creation of wealth. Culture has been traditionally considered from the point of view of "enlightenment". After the approach of "art for art's sake", we can say that a work of art is important because it enriches its beneficiaries by offering them the pleasure to admire the embodiment of "beauty", by broadening their "horizons" and/ or by providing them with a better understanding of the complexity of the human being. Culture performs multiple social and political functions. They often serve as justifications for cultural policies at a national level, which have gained a greater relevance in a globalized and multicultural world. (EU, 2011, p. 29)

\section{Quote 5: European Union}

The role of the cultural and creative sector in this context is still disregarded. In fact, the concern to measure the socioeconomic performance of the sector is a relatively recent trend. Also, the exercise is controversial. For many people, art is a matter of enlightenment or entertainment. That leads to the perception that arts and culture are marginal in terms of economic contribution and should, therefore, be limited to the public intervention domain. This can explain, to a large extent, the lack of statistical tools available to measure the contribution of the cultural sector to economy, whether at a national or at an international level, particularly compared to other industries.

\section{Quote 6. Cultural industries.}

The term cultural industries refers to industries that blend the creation, production and marketing of creative contents, which are intangible and of cultural nature. The contents are typically protected by copyright and they can take the form of a good or a service. Generally, cultural industries include printing, publishing and multimedia, audiovisual, phonographic and cinematographic productions, as well as crafts and design.

The term creative industries encompasses a wide range of activities including cultural industries, besides all cultural or artistic production, whether live or produced as an individual unit. Creative industries are those in which the product or service contains a substantial element of artistic or creative endeavor and they include activities such as architecture and advertising. [...] These terms [...] are not synonymous [...]. (UNESCO, 2013, p. 3)

\section{Quote 7}


Figure 1 - Different links of the creative industry chain in Brazil

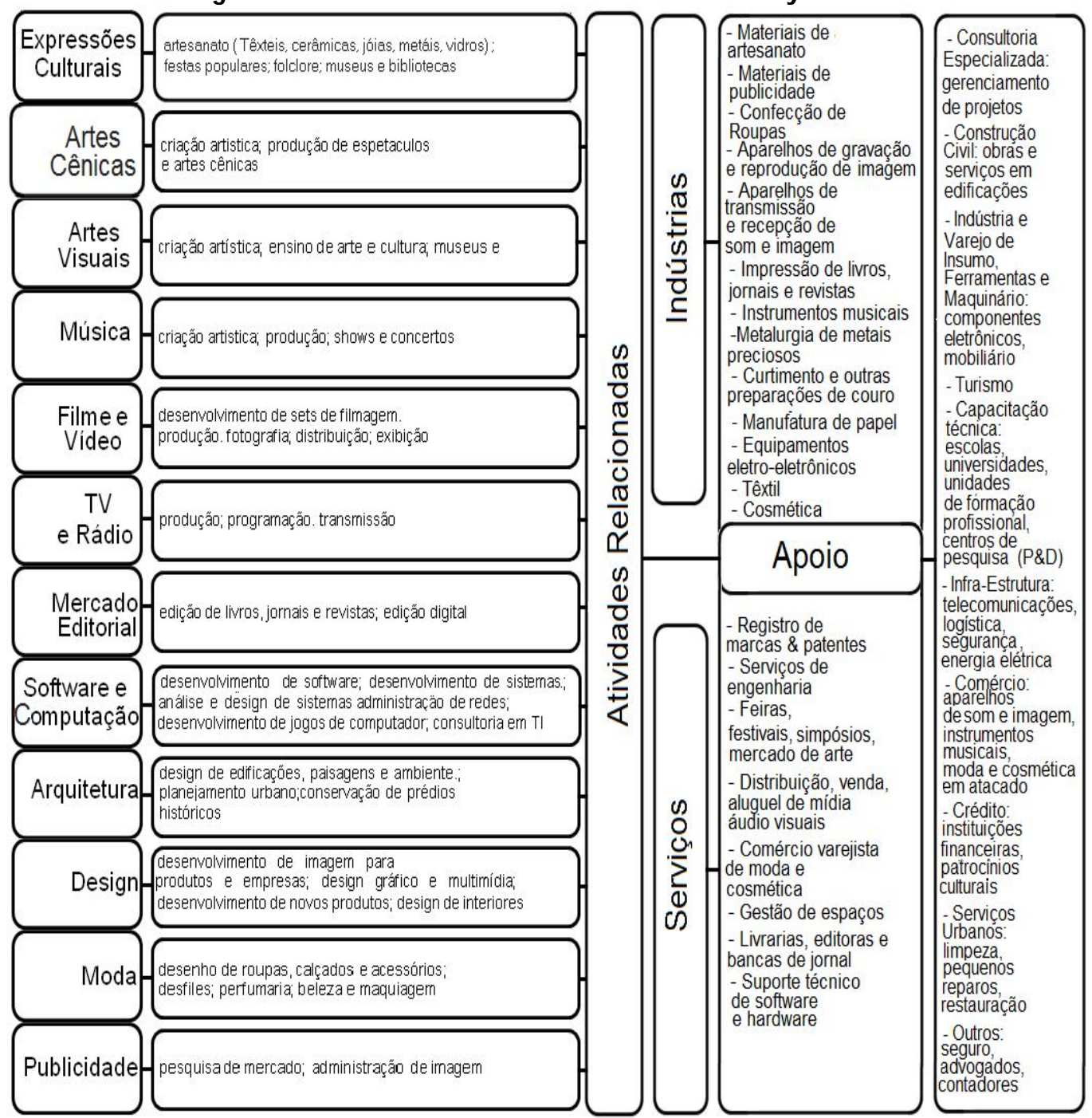

Source: FIRJAN, 2011

Cultural Expression: crafts (textiles, ceramics, jewelry, metal, glass, festivals, folklore, museums and libraries)

Performing Arts: artistic creation, performance production and performing arts

Visual Arts: artistic creation, teaching art and culture, museums

Music: artistic creation; production, concerts;

Films and Videos: developing movie sets. Production, photography, distribution, exhibition.

TV and Radio: production; programming; broadcasting

Publishing Market: editing books, newspapers, magazines; digital editing

Software and Computing: software development, systems development, systems analysis and design, network administration, computer games development, IT consulting 
Architecture: design of buildings, landscape and environments; urban planning, conservation of historic buildings

Design: image development for products and companies; graphic design and multimedia; development of new products; interior design

Fashion: Designing clothes, shoes and accessories; fashion parade; perfumery; beauty and makeup

Advertising: market research; image management

\section{RELATED ACTIVITIES}

\section{INDUSTRIES}

Craft supplies, advertising materials, clothing production, image recording and reproduction devices, sound and image transmission and reception devices, printing of books, newspapers and magazines; musical instruments; metallurgy of precious metals, tanning and other leather preparations; paper manufacturing; electrical and electronic equipment; textile; cosmetology.

\section{SUPPORT}

\section{SERVICES}

Trademarks and patents; engineering services; fairs, festivals, symposiums, art market; distribution, sales, rental of audio visual media; fashion and cosmetics retail; facility management; bookstores, publishers and newsstands; software and hardware technical support.

- Expert advice: project management

- Civil construction: construction and services in buildings

- Input Retail and industry, tools and machinery, electronic components, furniture

- Tourism

- Technical qualification: schools, universities, professional training institutions, research centers $(R \& D)$

- Infrastructure: telecommunications, logistics, safety, electric power

- Trade: audio and video devices, musical instruments, wholesale fashion and cosmetics;

- Credit: financial institutions, cultural sponsorships;

- Urban services: cleaning, small repairs, restoration

- Other: insurance, lawyers, accountants

Revista Galega de Economía: http://www.usc.es/econo/RGE/benvidag.htm https://ideas.repec.org.s/sdo/regaec.html 